\title{
From the Pulpits to the Boards: A Study on Prospective Second Career Teachers in Turkey
}

\author{
Ali Unisen ${ }^{1} \&$ Huseyin Polat ${ }^{2}$ \\ ${ }^{1}$ Adiyaman University, Turkey \\ Correspondence: Ali Unisen, Adiyaman University, Turkey. E-mail: aunisen@adiyaman.edu.tr
}

Received: December 16, 2015

Accepted: April 15, 2016

Online Published: August 29, 2016

doi:10.5539/ies.v9n9p170

URL: http://dx.doi.org/10.5539/ies.v9n9p170

\begin{abstract}
Teaching career is the widest state employment type in Turkey. The career is resourced by many higher education institutions besides the ones deploying regular teacher training programs. Teacher candidates other than the graduates from education faculties have to attend a program specially designed to instruct on foundations of education such as theories, principles, strategies, planning, teaching methods and assessment. That alternative teacher certification program paves the way to transition to teaching career as well. This study was carried out with 11 religious officials who intend to shift into teaching career. The data was collected through 5 essays written by each participant while they were attending the program. The study was conducted as content analyses of total 55 essays. The analyses revealed that the participants, 1 preacher-woman, 4 mosque leaders-preachers and 6 Quran instructors, did not display any role confliction, intended to use their skills and experiences developed through their current careers selectively. The results were discussed with relevant available literature.
\end{abstract}

Keywords: teacher training, second career teachers, religious culture and moral knowledge teaching

\section{Introduction}

The obligation to pursue a single career all along one's working life seems to be a thing of the past. Traditional understanding of the career has lost its validity as the diminishing demand for the product of the profession together with many other reasons compels individuals to change into another one and available opportunities pave the way for them. Job security, higher social status and better payment expectations, disillusionment at current job are some of the reasons known to lead career change (Khapova, Arthur, Wilderom, \& Svensson, 2007; Lent \& Lopez, 1996; Lovett, 2007).

Employment conditions and opportunities for career change is too limited in Turkey for the present; the problem of qualified personnel shortage for some jobs (Biçerli, 2011) and the problem of unemployed person with qualifications (Eser \& Terzi, 2008; Özpınar, Demir, \& Keskin, 2011) co-exist; meritocratic employment conditions are hardly met both from the point of employed and employee (Demirci \& Kocaman, 2007). The number of the individuals re-employed through career change is still negligible statically in total employed workers. Thus, the national literature is poor in this respect.

Career changing, in which teaching career stands on one end, has taken place in two ways so far: (a) civil servants who are employed for their high school attainments could accomplish their higher education in a regular teacher training program and be qualified for transition to teaching profession without taking the public personnel selection examination (PPSE) and (b) individuals who are employed as teachers-mostly class teachers-without attending a teacher training program are eligible to change position from teaching into fields for which they have been trained under suitable conditions. Both types of change are named inter-institutions transition, and applicants are not required to take PPSE.

Murat, Ünişen, and Kanadlı (2004) found teaching to be a lower priority career choice in Turkey even among the teacher candidates, but more preferable than the lower status civil services. The prerequisite relatively mediocre points in nation-wide-held university entrance examination to apply a regular teacher training program indicates the career's popularity level, which contradicts most of the researches conducted. Furthermore, there are researches which show that only one fourth of teacher candidates put teaching among the first-four choice in their career preference order (Özbek, 2007) and even in some, it is favored the $17^{\text {th }}$ or at a lower order (K1lcan, 
Keçe, Çepni, \& Kılınç, 2014). Findings of these researches contradict with the findings of the ones on teacher candidates' perception of the career, their attitudes towards the career, the reasons leading them to choose the career etc. (Çermik, Doğan, \& Şahin, 2010; Haciömeroğlu \& Taşkin, 2010; G. Özsoy, S. Özsoy, Özkara, \& Memiş, 2010).

Teaching career is preferred for various reasons such as its social status, career fit, financial reward, time for family, liking to work with children (Carless \& Arnup, 2011; Richardson \& Watt, 2005), which are thematized under intrinsic, extrinsic and altruistic reasons (Bob-Chui, 1995; Wagner \& Imanuel, 2014). In Turkey also the career is chosen -although not favored- for the same reasons (Özsoy et al., 2010).

With introduction of pedagogical formation program as an alternative teacher certification program in Turkey since 2011, thousands of bachelors of arts and sciences were certified as teacher candidates for various branches of secondary and high schools.

The current pedagogical formation program consists of 10 courses, of which eight are compulsory and two elective. It is implemented in two terms. In the former term, applicants take the common courses, namely, introduction to teaching profession, classroom management, educational psychology, teaching principles and methods, and measurement and evaluation in education. The latter term has field specific courses, namely, special teaching methods, teaching technologies and materials, teaching practice along with two elective courses, each chosen from a different pool -field elective and complementary elective.

Although similar programs are implemented in many countries, it differs in rationales from the ones implemented in the States (Mccarty, 2013; Morettini, 2014; Tigchelaar, Vermunt, \& Brouwer, 2014) and other countries (Howes \& Goodman-Delahunty, 2015; Williams, 2013, p. 12; Yıldırım \& Vural, 2014) as it is neither implemented as a solution to cover a current or forthcoming teacher shortage nor to expand the pool of qualified teacher for various subjects (Higher Education Council, 2015). Since the teacher candidates are certified for many of the branches in a regular training system at education faculties in numbers exceeding the posts available, the implementation is criticized as emerged due to social and political concerns (Ylldırım \& Vural, 2014).

The program was first implemented to license individuals graduated from faculties of arts and sciences as teacher candidates, and this licensure was to cover the teacher shortages in certain fields. Through the amendments over the time, it hardly excluded any graduate of faculties of arts and sciences including the ones from open and distant education faculties (Higher Education Council, 2014; Ministry of Education, 2014). Thus the program, on the one hand, made teaching an available career for anyone having a bachelor's degree and on the other hand, a second career choice for already-employed ones.

Relevant Turkish literature on teachers and teacher training deals only with teacher candidates in regular teacher training system and teacher pursuing it as the first career. The profession was repeatedly found to have a low social, economic and social profile among the teacher candidates (Murat et al., 2004; Özbek, 2007). But due to the reasons such as being the broadest field for job hunting and dictation of university entrance examination, there is a constant increase in the number of individuals choosing teaching as their prospective careers. In addition, certain reasons such as an average of 500 teaching hours spent per year in secondary education, which is far below the averages of the OECD countries' (OECD, 2015, p. 458), and much lower than the working hours of the ones with similar educational attainments among the state employed individuals in the country, and a steady increase in their income in the last decade (OECD, 2015, pp. 546-549) have contributed into the career's attraction to some extent. Because of the relatively higher life standards it offers and its easy-accessibility through Pedagogical Formation Program, teaching has also become the second career choice of some civil servants since 2011.

Different from the other two types of career change, this type of career changers have to take the PPSE and context with the ones with regular teacher training program in the same field. Since they expand the teacher selection pool, they are also supposed to have an implicit effect on increasing the teacher quality as well. They are mostly from social services suggesting that they have a higher teaching readiness and could make a better start than novice teachers. Indeed, career changers are observed to contribute into their teaching career with their work skills and experiences as well as with their broader life experiences (Anderson, Fry, \& Hourcade, 2014; Chambers, 2002; Justina, 2012; Mayotte, 2003; Mccarty, 2013; Resta, Huling, \& Rainwater, 2001; Wagner \& Imanuel, 2014). If this be so, the careers which they are changing from are supposed to shape the content and methodology of their teaching to a certain extend.

The participants of present research have a constructed professional identity developed through their particular institutional trainings and social interactions. As they are assigned in mass-education courses as instructors, they have teaching experiences as well. However, the courses which they are assigned as teachers are carried out in a 
devotional atmosphere; both the teachers and attendees share the same beliefs and try to conform to requirements of a particular belief. The content is mostly relayed in a teacher centered and didactic manner. Memory works and recitations form a significant part of mass education courses.

The Religious Culture and Moral Knowledge course in public schools differs from the religious courses designed for mass education in objectives and methodology. The ministry strictly prohibits infringements on freedom of religions and conscience, indoctrination and urging students to conform to practices of any particular belief. The curriculum suggests, even exhorts teachers to employ student centered technics and adopt an academic approach to their course, expose students to diversity of beliefs and religions (Ministry of Education, 2010, p. 9), all of which contradict with their current careers.

The present study will explore mosque leaders-preachers' and Quran course tutors' perception of teaching career in terms of the lesson they will teach, the methodology they will apply. The study will shed an implicit light on how the religion culture and moral knowledge will probably be constructed in the classrooms by second career teachers.

\section{Method}

\subsection{Participants}

The participants of the study were 11 teacher candidates out of 40 attendees in Religious Culture and Moral Knowledge group. Of the participants, 1 was preacher woman with an experience of 6 years, 6 Quran instructors whose experiences ranged from 3 to 9 years and 4 mosque leader-preachers with 6 to 12 years of service. The participants were chosen purposively as they had current jobs which had much in common with teaching but could create inter-role confliction.

\subsection{Data Collection}

The present study was conducted as open-ended written questionnaire. Data for the study was gathered from five sessions over a period of nine weeks starting from the $5^{\text {th }}$ week of the latter semester of the program. Every other week, teacher candidates were asked to answer a question in essay type. Each participant wrote five essays as answers to:

a) The similarities and differences between their current job and teaching,

b) Why their teaching subject should be compulsory/elective,

c) How they would make use of their prior experiences to teach their subjects better,

d) What should be the best content for religious culture and moral knowledge lesson, and

e) What they would do to improve students' involvement.

Prior to the involvement, the participants were informed that the data would be used in a research with their consent, they did not have to participate in or could leave any time they liked or miss any session and the questions did not have satisfying answers. In an attempt to assure the validity, the study was conducted with all participants to elicit various opinions, the questions were posed clearly, the data were gathered in written form from the participants, and each time they were assigned to write, they were reminded not to bother with the layout and mechanics of essay writing so that they could focus on the content (Cohen, Manion, \& Morrison, 2012, p. 150; Yin, 2012, p. 79).

The data was collected by the first researcher, who was also the instructor of educational technologies and materials. To obtain their voluntary consent, participants were clearly informed of the purpose of the research, its duration, how the anonymity of the data would be assured, that they could be informed on results of the research if they liked, and their dis/involvement in the research as participants would not affect their performance in the course given by the instructor.

\subsection{Data Analysis}

The essays were copied without the participants' identity details. Each essay was named binary as Tx-Ex, where Tx stood for the participant, and Ex for session number. Before the conduction of analyses, responses of three participants were read through by a field expert to find the codes and themes. Then the essays written by the 11 participants were sorted under the five headings. Total five sets of essays, consisting of 11 responses from the participants were read and coded by the researchers. The codes and themes determined by the field expert were checked with the ones found by the researchers independently and at different times. Final codes and themes were decided consensually and analyzed. The results were presented quasi-statistically for internal generalization (Maxwell, 2010). 


\section{Results}

The study was conducted with 11 participants with bachelor's degrees from faculties of theology. The participants have teaching experiences in common-public education ranging from 3 to 12 years. They also had a teaching experience of 30 class hours at state schools when the study started.

Table 1. Demographics of the participants

\begin{tabular}{lccc}
\hline Current Career & Gender & $\mathrm{f}$ & $\%$ \\
\hline Quran Instructor & $\mathrm{F}$ & 6 & 54,5 \\
Mosque leader-Preacher & $\mathrm{M}$ & 4 & 36,4 \\
Preacher Woman & $\mathrm{F}$ & 1 & 9,1 \\
\hline
\end{tabular}

As seen in the table, 7 of the participant were female and 4 were male. They ranged from 27 to 36 in age.

Since the majority of the participants did not volunteer to share their reflections concerning the motives and experiences associated with leaving current career to pursue teaching career, relevant literature was reviewed and lower rank religious officials were found the higher educational backgrounds they had, the more decreased attitudes towards their career they developed and lost their motivation to pursue it (Çoştu, 2013; Kaya and Nazıroğlu, 2008), and certain studies showed that teaching career would be their first choice if they were to change from religious officials (Kaya \& Nazıroğlu, 2008; Y1ldız, 2012).

\subsection{The Similarities and Differences between Their Current Job and Teaching}

Second career prospective Religious Culture and Moral Knowledge teachers (RCMKT) in the program were asked to reflect on comparison of their current and intended careers. The participants responded to the following open-ended question "What are the common and distinguishing characteristics of a RCMKT and a religious official (RO)?"

Table 2. Comparative perception of current and prospective careers

\begin{tabular}{|c|c|c|c|}
\hline Themes & Careers & Codes & f $\%$ \\
\hline \multirow{4}{*}{ Time and Environment } & \multirow{2}{*}{ RCMKT } & Having a definite working schedule & 218.2 \\
\hline & & Being limited within schools & 218.2 \\
\hline & \multirow{2}{*}{ RO } & Not limited within mosques/houses of prayer & 327.3 \\
\hline & & Not having a working schedule/always on-duty & 19.1 \\
\hline \multirow{5}{*}{ Methodology } & \multirow{4}{*}{ RCMKT } & Relaying knowledge & 327.3 \\
\hline & & Using technology & 218.2 \\
\hline & & Expanding students horizons & 19.1 \\
\hline & & Empathizing with students & 19.1 \\
\hline & RO & Teaching practices & $4 \quad 36.4$ \\
\hline \multirow{5}{*}{ Motivation in Teaching } & Same & Creating moral individuals and societies & 327.3 \\
\hline & \multirow{2}{*}{ RCMKT } & Feeling extrinsic obligation & 19.1 \\
\hline & & Having to know all elements making a society besides his subject & 19.1 \\
\hline & \multirow{2}{*}{ RO } & Being ruled by intrinsic motivation & 218.2 \\
\hline & & Working on a volunteer basis (duties of our job definition) & 19.1 \\
\hline \multirow{4}{*}{ Professional Necessities } & \multirow{4}{*}{ RCMKT } & Having more pedagogical knowledge & 327.3 \\
\hline & & Having to update him/herself more frequently & 218.2 \\
\hline & & Being restricted with the curriculum & 19.1 \\
\hline & & Having better communication skills with students & 19.1 \\
\hline
\end{tabular}




\begin{tabular}{llll}
\hline & Acting/talking in an inclusive manner & 1 & 9.1 \\
Being more informed in the field & 2 & 18.2 \\
Acting more maturely/appearing demure & 2 & 18.2 \\
RO $\quad$ Being more social & 1 & 9.1 \\
Reading more & 1 & 9.1 \\
Playing a role model on all stages of life & 1 & 9.1 \\
Being active participant in every sphere of life & 1 & 9.1 \\
\hline
\end{tabular}

The participants passed their opinions on strength and weaknesses of either career presupposing both were same types of jobs, which contributed to individuals and society with different motives, identities and methods (Table 2). They thought RCMK and RO careers differed from each other in many aspects such as the work schedule and environments, the methodology they applied, the motivation to meet their jobs' responsibilities and professional necessities of either career. However, the low frequencies of codes implied that the differences appeared slight.

They described themselves in their current role as officials whose jobs were not limited within a building (27.3\%) and a schedule $(9.1 \%)$, aiming at teaching religious practices $(36,4 \%)$, ruled by intrinsic motivation $(18.2 \%)$ and voluntarily (9.1\%). They thought they were also expected to be more informed in theological sciences $(18.2 \%)$, to act more maturely $(18.2 \%)$ and with the same frequencies $(9,1 \%)$ to read more, be social, participate all social activities and be the role model in society.

They found teaching to be confined within schools $(18.2 \%)$ and time tables $(18.2 \%)$, relaying rote information $(27.3 \%)$ which was restricted with the curriculum $(9.1 \%)$, and performed with extrinsic motivation $(9.1 \%)$. On the other hand, they appraised teaching for requiring more pedagogical knowledge $(27.3 \%)$, obligation to update itself more frequently $(18.2 \%)$. The participants believed that the teachers had better communication skills with teenagers $(9.1 \%)$, used more instructional technologies $(18.2 \%)$, tried to expand the students' horizons $(9.1 \%)$, were better in empathizing with students (9.1\%), not limited with a definite discipline (9.1\%).

As observed from the responds, except for the work schedule, working environment and motivation, they did not report any dichotomies in themes.

\subsection{Why Their Teaching Subject Should Be Compulsory/Elective}

Religious culture and moral knowledge course is currently in compulsory status at state schools except for the non-Muslim students. The status of the course, even its existence has always been a controversial issue among politicians and certain non-governmental organizations. The participants were asked to pass their remarks on which side they stood.

Table 3. Views dealing with status of RCMK course

\begin{tabular}{lllll}
\hline Views & Themes & Codes & $\mathrm{f}$ & $\%$ \\
\hline Compulsory & & Bringing up moral individuals & 1 & 9.1 \\
\hline \multirow{3}{*}{ Elective } & \multirow{3}{*}{ Freedom of belief } & Various faiths exist & 5 & 45.5 \\
& & Freedom to choose religion & 2 & 18.2 \\
& & Right of choosing contributes more into individual and social & 1 & 9.1 \\
& & development & 1 & 9.1 \\
\cline { 3 - 5 } & & A requirement of secularism & 2 & 18.2 \\
& \multirow{2}{*}{ Academic Achievement } & More efficient learning & 1 & 9.1 \\
\hline & & Learning requires volunteerism &
\end{tabular}

As seen in the Table 3 only one of the participants thought that their subject had to be compulsory $(9.1 \%)$. She claimed bringing up moral individuals hence a moral society could be better ensured with legal regulation. Remaining participants (90.9\%) surprisingly favored their subject to be in elective status. Their rationales were thematized under headings of freedom of belief and academic achievement. 
Of the participants, a great majority (45.5\%) thought, as various faiths existed in Islam, the course should be optional. Other participants justified their views with freedom to choose religion $(18.2 \%)$, choosing would make a healthier society $(9.1 \%)$ and secularism required choosing $(9.1 \%)$. As for the rationales dealing with academic achievement, the participants suggested a better learning atmosphere could be created (18.2\%) were the subject optional and learning required volunteerism $(9.1 \%)$.

\subsection{How They Would Make Use of Their Prior Experiences to Teach Their Subjects Better}

In the $9^{\text {th }}$ week of latter term of the program, when the participants had 54-60 hours of teaching experience at states schools as RCMKTs, they were asked to reflect on how they could benefit from their experiences developed through their current careers and what type teachers they would play in future.

Table 4. Contribution of prior careers to teaching career

\begin{tabular}{llll}
\hline Theme & Code & $\mathrm{f}$ & $\%$ \\
\hline \multirow{5}{*}{ Content-Related } & Ability to align the subject with individual and social needs & 7 & 63.6 \\
& Prioritizing affective domain to cognitive domain & 5 & 45.5 \\
& Having witnessed practice of knowledge taught & 2 & 18.2 \\
& Having knowledge and practice strengthening each other & 1 & 9.1 \\
\hline \multirow{5}{*}{ Methodology } & Enriching and diversifying learning environments & 5 & 45.5 \\
& Avoiding rote learning & 2 & 18.2 \\
& Designing proper content for each age group & 2 & 18.2 \\
& Having better communication skills & 2 & 18.2 \\
& Avoiding assessment in the form marking & 1 & 9.1 \\
& Designing an inclusive content & 1 & 9.1 \\
& Being a role model of what their subject dictates/rules & 1 & 9.1 \\
& Volunteering to participate in any school activity & 1 & 9.1 \\
\hline \multirow{2}{*}{ Planning } & To improve their pedagogical knowledge & 2 & 18.2 \\
& To study for master degree & 1 & 9.1 \\
\hline
\end{tabular}

The participants views were grouped under three themes; skills related to the content, methodological enrichment and plans for future (Table 4). They thought, as they knew what role the religion culture and moral knowledge played in the society, they could align the subject with social and individual needs better (63.6\%), they would prioritize affective domain rather than cognitive one (45.5\%), balance the theory and practice $(18.2 \%)$ and support the knowledge with practice $(9.1 \%)$. They also believed that they could do better at enriching and diversifying the learning environment either in school or extramural $(45.5 \%)$, avoiding the methods leading to rote learning (18.2\%), designing the proper content for each age group (18.2\%), using their communication skills (18.2\%) (developed through oratorical training). At a lower frequency (9.1\%), they stated that they could design a more inclusive content for each subject and age group; they were acting the moral individual they intended to create; they would volunteer to participate in all school activities.

One of the participants (9.1\%) found assessment in religious and moral matters weird. He argued affective behaviors are degraded when marked.

Under the theme of planning $18.2 \%$ of participants discussed, although they pursued a teacher-like career currently, they still need to improve their pedagogical knowledge in some way, and another $9.1 \%$ had intension to study for master degree on education for the same reason.

\subsection{Views on the Best Content for RCMK Lesson}

The participants were asked to write their views dealing with what the best content for their subject should be and what rationales they offered. Their views on objectives of the subject were thematized under its individual, social and political contribution, and on its content under religious culture and moral knowledge. 
Table 5. Views on the best content for RCMK course and rationales

\begin{tabular}{|c|c|c|c|}
\hline & Themes & Codes & f $\%$ \\
\hline \multirow{7}{*}{ Contribution } & \multirow{4}{*}{ Individual } & Bringing up moral individuals & 654.5 \\
\hline & & Teaching human values & 327.3 \\
\hline & & Fostering philanthropy & 218.2 \\
\hline & & Teaching individual responsibilities & 218.2 \\
\hline & \multirow{2}{*}{ Social } & Raising beneficial individuals for society & 327.3 \\
\hline & & Teaching social values & 218.2 \\
\hline & Political & Citizenship education & $\begin{array}{ll}1 & 9.1\end{array}$ \\
\hline \multirow{5}{*}{ Content } & \multirow{4}{*}{ Religious Culture } & Teaching religious knowledges & 218.2 \\
\hline & & Teaching about divine religions & 19.1 \\
\hline & & Teaching about both life and after-life & 19.1 \\
\hline & & Teaching Islamic-faith & 19.1 \\
\hline & Moral Education & Teaching moral values & 654.5 \\
\hline
\end{tabular}

As seen in the Table 5, religious education and religious culture concepts did not converge although a slight emphasize on Islamic faith was observed. They had congruent views on the current curriculum and textbooks for the subject. They thought the content should focus on teaching moral values $(54.5 \%)$ and at lower frequencies on teaching religious knowledge (18.2\%), divine religions $(9.1 \%)$, both life and after-life $(9.1 \%)$ and Islamic-faith $(9.1 \%)$ respectively. They stated the content had to contribute to bringing up moral individuals $(54.5 \%)$, teaching human values $(27.3 \%)$, teaching to respect each other $(18,2 \%)$ and teaching responsibilities $(18.2 \%)$. They regarded their subject to have social and political objectives as well such as bringing up socially beneficial individuals (27.3\%), teaching social values $(18,2 \%)$ and a means of citizenship education $(9.1 \%)$.

\subsection{What They Would Do to Improve Students' Involvement}

The participants observed a relatively low students' involvement even disinterest in their presentations during their teaching practices, which did not satisfy their expectations. Following a teaching experience of 72-78 hours at state schools, they were assigned to write an essay on what could improve students' involvement. Their views were thematized under suggestions dealing with teachers' qualities, methodology and curriculum design.

Table 6. Participants' view on improving students' involvement

\begin{tabular}{llll}
\hline Themes & Codes & f & $\%$ \\
\hline & Endearing him/herself & 4 & 36.4 \\
& Being the model inspired by the subject & 2 & 18.2 \\
Teacher & Being humorous and cheerful & 1 & 9.1 \\
& Having a good command of subject & 1 & 9.1 \\
& Avoiding punishment of any kind & 1 & 9.1 \\
& Being open to criticism & 1 & 9.1 \\
& Being free of any sort of prejudices & 1 & 9.1 \\
& Making students feel dignified & 3 & 27.3 \\
& Arranging excursions and observations & 2 & 18.2 \\
Methods & Considering the students' cognitive capacity & 2 & 18.2 \\
& Using drama & 1 & 9.1 \\
& Creating thought and discussion groups & 1 & 9.1 \\
& Relating the subject with the real life & 1 & 9.1 \\
\hline
\end{tabular}




\begin{tabular}{llll} 
& Concretizing the content & 1 & 9.1 \\
& Making use of instructional technology & 1 & 9.1 \\
& Using stories and anecdotes & 1 & 9.1 \\
Making use of games (at lower grades) & 1 & 9.1 \\
& Enriching the subject with extracurricular activities & 1 & 9.1 \\
& Using absorbing materials & 1 & 9.1 \\
Avoiding narration when possible & 1 & 9.1 \\
Developing cross-curricular materials & 1 & 9.1 \\
& Discussing daily issues & 1 & 9.1 \\
& Inviting experts/guests & 1 & 9.1 \\
& Developing efficient parent-teacher association & 1 & 9.1 \\
& More relevant content & 1 & 9.1 \\
& Textbooks should be richer in pictures & 1 & 9.1 \\
& Decreasing the content & 1 & 9.1 \\
Curriculum & 4 & 36.4 \\
\hline \multirow{2}{*}{ Assessment and Evaluation } & Devising an evaluation out of marks & 2 & 18.2 \\
\hline
\end{tabular}

They passed on their remarks developed through both their current careers and teaching experiences (Table 6) stating that RCMKTs had to endear themselves $(36.4 \%)$, be the model what their subject dictated $(18.2 \%)$, be humorous, have a good command of field knowledge, avoid any kind of punishment including reproving, welcome criticism, avoid any kind of prejudices $(9.1 \%$ each), all of which were expected in their current careers as well.

As for the methodology, they offered rich means to provide students' interest, many of which were hardly ever implemented currently in their prospective subject such as arranging excursions and observations (18.2\%), creating thinking and discussion groups, making use of games, enriching the subjects with extracurricular activities, developing cross-curricular instructional materials and inviting guests/experts for certain course subjects $(9.1 \%$ each). Affective security $(27.3 \%)$ was regarded to play the key role in students' involvement, which was followed by considering the students' cognitive capacity $(18.2 \%)$, using drama, relating the subjects with the real life, concretizing the content, making use of instructional technologies, using stories and anecdotes, using absorbing materials, avoiding narration as much as possible, discussing daily issues, developing efficient parent-teacher associations ( $9.1 \%$ each).

As they had congruent views with the curriculum and textbooks, they had fewer suggestions dealing with curriculum. However, they thought the content could be more relevant and be decreased, and textbooks should contain more visuals $(9.1 \%$ each).

They thought assessment of their subject were not any different than the assessment of any subject which prioritized developing cognitive behaviors. As an assessment in the form of marking degraded the objectives of the course, they stated an alternative to marking (36.4\%) could work better. Rewarding achievements other than in cognitive domain (18.2\%) could address the objectives of the course better.

\section{Conclusion and Discussion}

Religious culture and moral knowledge lesson, like certain other liberal arts subjects such language and literature, history, citizenship and values education, is one of the significant means used in education to sustain cultural continuity and sufficient homogeneity. Although both the curriculum and text books are written in Islamic terminology dominantly, they do not impose any single faith-of the majority-on students but rather inseminate pursuance of moral lives, understand and respect differences. Both the existence of the lesson in the curriculum either elective or compulsory, and the content and quality of the lesson have been a contentious issue since the Foundation of the Republic; the same curriculum might be harshly criticized as posing threats to secularism by some groups claiming that it is dominantly Islamic faith-based education while by some others for downplaying or neglecting the expectations of majority (Bulut, 2011; Kaymakcan, 2007; Yıldız, 2009; Zengin, 2013).

The course is thought by RCMK teachers with regular teacher training mostly but since the introduction of 
pedagogical formation program in 2011, it has been liable to be an available career for any candidate graduated from faculties of theology either as a jobseeker or a career changer. This study explored the cases of 11 career changer teacher candidates, of whom 6 were Quran instructors, 4 mosque leader-preachers and 1 was preacher woman.

The analysis of responses to the essay type questions indicated that career changers who intend to become RCMK teachers at secondary and high schools offered promises far above the expectations; their intentions of transferring their previous professional experiences and content expertise into teaching combined with their maturity confirmed Anderson et al. (2014). From their views dealing the best content for their subject in a multicultural society and the comparison of their current and intended careers, we concluded that they would hardly experience inter-role conflicts. Although they were religious officials in religious education, they respected secularism. They regarded religion culture and moral knowledge as a means of uniting individuals or homogenizing the society around moral and human values.

As the participants offered learner-oriented practices, sustaining differences and diversity, avoiding a single faith based content, which conflicted in some aspects with religious education and what they did in their current careers, they were seen to be highly conscious of what to choose and what to leave from the experiences that they had developed through their current careers. Self-regulation capacity required to adapt to changes (van Beek, de Jong, Minnaert, \& Wubbels, 2014) was observed from their opinions on common and distinguishing characteristics of their current and prospective careers. They persisted in learner-oriented practices during their teaching practices at school during the data collection period. As the period was rather short, the results could not test whether their instructional practices would converge with the first career teachers' practices after a definite period (Powell, 1997).

As Powers (2002) also found in his study, the participants were more eager to find the similarities between their current and prospective careers. They viewed themselves play many parts of their prospective teaching roles currently in many aspects. Similarities they found between their current and prospective careers outnumbered the differences. Although the skills they developed in their current career resembled the ones benefited in formal learning environments, they reported unsatisfying students' interest into their subject, which confirmed the problems reported in transferring previous career skills into teaching (Tigchelaar, Brouwer, \& Vermunt, 2010).

The coherence between their remarks dealing with their second career, their subject and the methodologies that they intended to employ implied promising prospective teachers.

\section{Limitations}

The participants had 30 hours of teaching experience in public schools when they first asked to write, and 78 hours of experience in the last session. As they taught their subjects in presence of advisor teachers in public schools, they might not have faced any classroom management challenges. A longitudinal study with the same participants with real teaching experiences may provide more reliable results.

\section{Acknowledgements}

Authors contributed the study equally.

\section{References}

Anderson, H., Fry, S., \& Hourcade, J. J. (2014). Career changers as first-year high school teachers. The Clearing House: A Journal of Educational Strategies, Issues and Ideas, 87(4), 149-154. http://dx.doi.org/10.1080/00098655.2013.878302

Biçerli, M. K. (2011). We have to re-structure our higher education system in parallel with the developments in the labor market. Journal of Higher Education and Science, 1(3), 122-127. http://dx.doi.org/10.5961/jhes.2011.018

Bob-Chui, S. Y. (1995). Teacher trainess' motivation for entering into a teaching career in Brunei Darussalam. Teaching and Teacher Education, 11(3), 275-280. http://dx.doi.org/10.1016/0742-051X(94)00023-Y

Bulut, R. (2011). The social basis and functions of religious education at schools. Usak University Journal of Social Sciences, 4(1), 20-37.

Carless, S. A., \& Arnup, J. L. (2011). A longitudinal study of the determinants and outcomes of career change. Journal of Vocational Behavior, 78(1), 80-91. http://dx.doi.org/10.1016/j.jvb.2010.09.002

Chambers, D. (2002). The real world and the classroom: Second-career teachers. The Clearing House: A Journal of Educational Strategies, Issues, and Ideas, 75(4), 212-217. http://dx.doi.org/10.1080/00098650209604935 
Cohen, L., Manion, L., \& Morrison, K. (2012). Research methods in education: professional development in education (6th ed.). New York: Routledge

Çermik, H., Doğan, B., \& Şahin, A. (2010). Prospective elementary classroom teachers' motives for selecting teaching profession. Pamukkale Üniversitesi Ë̆itim Fakültesi Dergisi, (28), 201-212.

Çoştu, Y. (2013). Job satisfaction of religious officials; Çorum case. Hitit Üniversitesi Sosyal Bilimler Enstitüsü Dergisi, 6(1), 1-18.

Demirci, A., \& Kocaman, S. (2007). The evaluation of employability of geography graduates in the field of geographical information systems. Marmara Coğrafya Dergisi, 16, 65-92.

Eser, B. Y., \& Terzi, H. (2008). The unemployment in Turkey and European employment strategy. Erciyes Üniversitesi İktisadi ve İdari Bilimler Fakültesi Dergisi, 30, 229-250.

Haciömeroğlu, G., \& Taşkin, Ç. Ş. (2010). Preservice teachers' attitudes towards teaching profession in primary and secondary education. Ahi Evran Üniversitesi Eğitim Fakültesi Dergisi, 11(1), 77-90.

Higher Education Council. (2014). Procedures and principles dealing with pedagogical formation training program. $\quad$ Retrieved November $29, \quad 2015$, from http://www.yok.gov.tr/web/guest/icerik/-/journal_content/56_INSTANCE_rEHF8BIsfYRx/10279/7052802

Higher Education Council. (2015). News release on pedadogical formation program certification. Retrieved November 29, 2015, from http://www.yok.gov.tr/documents/10279/19836547/Pedagojik_Formasyon_ Egitimi_Sertifika_Programlari_Hakkinda_Aciklama.pdf

Howes, L. M., \& Goodman-Delahunty, J. (2015). Teachers' career decisions: Perspectives on choosing teaching careers, and on staying or leaving. Issues in Educational Research, 25(1), 18-35.

Justina, T. (2012). Second career teachers: Perceptions of self-efficacy in the first year of teaching. New Horizons in Education, 60(2), 21-36.

Kaya, M., \& Nazıroğlu, B. (2008). Certain factors affecting religious officials' professional attitudes and motivation levels. Ondokuz Mayıs Üniversitesi İlâhiyat Fakültesi Dergisi, (12), 25-53.

Kaymakcan, R. (2007). A report of inspection and survey of new secondary religious culture and moral knowledge curriculum. İstanbul. Retrieved from http://erg.sabanciuniv.edu/sites/erg.sabanciuniv.edu/files/ Din.Kulturu.ve_.Ahlak_.Bilgisi.Og_Prog_.Inc_.12_04_07_0.pdf

Khapova, S. N., Arthur, M. B., Wilderom, C. P. M., \& Svensson, J. S. (2007). Professional identity as the key to career change intention. Career Development International, 12(7), 584-595. http://dx.doi.org/10.1108/13620430710834378

Kılcan, B., Keçe, M., Çepni, O., \& Kılınç, A. Ç. (2014). Prospective Teachers' reasons for choosing teaching as a profession. Kastamonu Education Journal, 22(1), 69-80.

Lent, E., \& Lopez, F. (1996). Congruence from many angles: Relations of multiple congruence indices to job satisfaction among adult workers. Journal of Vocational Behavior, 37(49), 24-37. http://dx.doi.org/10.1006/jvbe.1996.0031

Lovett, S. (2007). "Teachers of Promise": Is teaching their first career choice? New Zealand Annual Review of Education, (16), 29-53.

Maxwell, J. A. (2010). Using numbers in qualitative research. Qualitative inquiry, 16(6), 475-482. http://dx.doi.org/10.1177/1077800410364740

Mayotte, G. A. (2003). Stepping stones to success: Previously developed career competencies and their benefits to career switchers transitioning to teaching. Teaching and Teacher Education, 19(7), 681-695. http://dx.doi.org/10.1016/j.tate.2003.03.002

Mccarty, W. L. (2013). Transition to teaching in Nebraska: Findings from the first decade. Journal of the National Association for Alternative Certification, 8(1), 3-15.

Ministry of Education. (2010). Secondary education religious culture and moral knowledge course curriculum. Ankara: MEB.

Ministry of Education. (2014). Changes dealing with teaching branches, appointment and teaching principles. Periodical of Notices, 77(2683), 1218-1222.

Morettini, B. W. (2014). Going back to school: Why STEM professionals decide to teach through alternative 
certification programs. Journal of the National Association for Alternative Certification, 9(2), 3-23.

Murat, M., Ünişen, A., \& Kanadlı, S. (2004). Freshmen teacher candidates' attitudes toward teaching career and their perceptions of the career. Esosder, 9(33), 226-244.

OECD. (2015). Education at a glance 2015: Indicatiors. OECD Publishing. http://dx.doi.org/10.1787/eag-2015-en

Özbek, R. (2007). Teacher candidates' perceptions about importance of personal, economical and social factors which effect their decissions to be teachers. Firat University Journal of Social Science, 17(1), 145-159.

Özpınar, Ş., Demir, Ö., \& Keskin, S. (2011). Assessment of the employment structure in Turkey. Sosyal ve Beşeri Bilimler Dergisi, 3(2), 133-142.

Özsoy, G., Özsoy, S., Özkara, Y., \& Memiş, A. D. (2010). Factors affecting pre-service teachers' choice of teaching as a profession. Elementary Education Online, 9(3), 910-921.

Powell, R. R. (1997). Teaching alike: A cross-case analysis of first-career and second-career beginning teachers' instructional convergence. Teaching and Teacher Education, 13(3), 341-356. http://dx.doi.org/10.1016/S0742-051X(96)00027-3

Powers, F. W. (2002). Second-career teachers: perceptions and mission in their new careers. International Studies in Sociology of Education, 12(3), 303-318. http://dx.doi.org/10.1080/09620210200200095

Resta, V., Huling, L., \& Rainwater, N. (2001). Preparing second-career teachers. Educational Leadership, 58(8), 60-63.

Richardson, P. W., \& Watt, H. M. G. (2005). "I've decided to become a teacher": Influences on career change. Teaching and Teacher Education, 21(5), 475-489. http://dx.doi.org/10.1016/j.tate.2005.03.007

Tigchelaar, A., Brouwer, N., \& Vermunt, J. D. (2010). Tailor-made: Towards a pedagogy for educating second-career teachers. Educational Research Review, 5(2), 164-183. http://dx.doi.org/10.1016/j.edurev.2009.11.002

Tigchelaar, A., Vermunt, J. D., \& Brouwer, N. (2014). Patterns of development in second-career teachers' conceptions of teaching and learning. Teaching and Teacher Education, 41(2014), 111-120. http://dx.doi.org/10.1016/j.tate.2014.04.001

van Beek, J. A., de Jong, F. P. C. M., Minnaert, A. E. M. G., \& Wubbels, T. (2014). Teacher practice in secondary vocational education: Between teacher-regulated activities of student learning and student self-regulation. Teaching and Teacher Education, 40, 1-9. http://dx.doi.org/10.1016/j.tate.2014.01.005

Wagner, T., \& Imanuel, D. (2014). Are they genuinely novice teachers? Motivations and self-efficacy of those who choose teaching as a second career. Australian Journal of Teacher Education, 39(7), 31-57. http://dx.doi.org/10.14221/ajte.2014v39n7.5

Williams, J. (2013). Constructing new professional identities: Career changers in teacher education. Rotterdam: Sense Publishers. http://dx.doi.org/10.1007/978-94-6209-260-0

Yıldırım, İ., \& Vural, Ö. F. (2014). Problems related with teacher training and pedagogical formation in Turkey. Journal of Teacher Education and Educators, 3(1), 73-90.

Yıldız, İ. (2009). The religious culture and ethics course: Should it be optional or cumporsory? Journal of Turkish Science-Research Foundation, 2(2), 243-256.

Yıldız, M. C. (2012). Religious officials and religious services in terms of sociology of professions. In Uluslararası Medrese ve ílahiyat Kavşağında İslamî İlimler Sempozyumu. Bingöl. http://dx.doi.org/10.1017/CBO9781107415324.004

Yin, R. K. (2012). Qualitative research from start to finish. New York: Guilford Press.

Zengin, M. (2013). Educational competence perceptions of the teachers of religious culture and ethical knowledge. Sakarya University Journal of Faculty of Theology, 15(27), 1-28. 


\section{Copyrights}

Copyright for this article is retained by the author(s), with first publication rights granted to the journal.

This is an open-access article distributed under the terms and conditions of the Creative Commons Attribution license (http://creativecommons.org/licenses/by/4.0/). 